\title{
INCIDENCE OF COLOURBLINDNESS AMONG FOUR ENDOGAMOUS NOMADIC GROUPS: AN EXAMPLE OF NATURAL SELECTION
}

\author{
K. C. MALHOTRA,* G. S. MUTALIK, $\dagger$ B. V. BHANU, $\$$ S. L. KATE $\dagger$ and \\ P. M. FULMALI+
}

Received 2.iii.73

\section{SUMMARY}

\begin{abstract}
Incidence of colourblindness among 1501 (945 males and 656 females) persons belonging to four nomadic Mendelian isolates, the Nandiwallas of Maharashtra, India, has been reported. Out of the four groups, three lacked the gene for colourblindness, while in one group the incidence was rather low $(0.3$ per cent). Our findings support the differential selection hypothesis for this loci of Post (1962) and Pickford (1963). 110 families with 334 children were examined for the inheritance of this trait. All matings except one were of the type normal $x$ normal and produced all normal children; the one family of the type father colourblind $x$ normal mother, also had all the six children with normal colour vision. The implications of the loss of the colourblind gene has been discussed in the light of nomadic way of the Nandiwallas, and also of their small effective popula tion sizes.
\end{abstract}

\section{InTRODUCTION}

Out of the many known loci in Man, the gene for colourblindness has been studied quite extensively. The genetics of this trait is well established, as is also its incidence in various populations of the world. The colourblindness trait provides excellent, and thoroughly worked out, evidence of the mechanism of natural selection. Concrete evidence for the concept of relaxed natural selection has also come through the study of this trait.

Post (1962) and Pickford (1963) postulated that the incidence of colourblindness will be different in various types of populations, and would depend upon whether they are $(a)$ hunters and food gatherers, $(b)$ somewhat removed from hunting and gathering-settled agriculturists etc., and (c) groups most removed from hunting and gathering-mostly urban communities. The incidence will be in the order highest among the people of category $(c)$ and lowest among category $(a)$. The available data for different populations are in full agreement with this postulate of Post and Pickford.

The incidence of colourblindness in Indian populations fits into the above hypothesis extremely well. Unfortunately, although data on this trait are available from higher and lower caste Hindus and also Indian tribals, data on nomadic groups are conspicuous by their absence. A review of the Indian literature on colour blindness can be found in Dutta (1966).

The purpose of this paper is to report the incidence of colourblindness among the four nomadic Mendelian isolates, the Nandiwallas from Maharashtra; to add additional family data on this trait; to test the PostPickford hypothesis; to discuss the findings in the light of the very small

* Indian Statistical Institute, Calcutta, c/o Deccan College, Poona-6, India.

$\dagger$ B.J. Medical College, Poona.

$\ddagger$ Deccan College, Poona-6. 
numerical strength of these groups and their nomadic nature; and to discuss the significance of the present findings in relation to the other genetic markers investigated in these people.

The present paper is the outcome of a multidisciplinary research project undertaken among the Nandiwallas in July-September 1969 and followed up in July-September 1972. The Nandiwallas migrated into Maharashtra from Andhra Pradesh, India, about 800 years ago. Their main profession is bull training. They are divided into four strictly endogamous groupsPatil Putta, Ghaugule Putta, Komti Putta and Daundiwallas. In addition to both types of cross-cousin marriages, they also prefer uncle-niece marriage. They are true nomads, and assemble once in three years at the village, Wadapuri in the Indapur Taluka of Poona District. For further ethnographic details see Malhotra (1972, 1973a).

\section{Methods and materials}

A total of 1501 Nandiwallas, including 945 males and 656 females age $7-65$, belonging to the four endogamous isolates, were examined for this trait. The number of subjects examined with respect to each group are set out in table 1. In addition, 110 families from Patils (35), Chaugules (41), Komtis (30) and Daundiwallas (4) were studied. 334 children (162 males and 172 females) belonging to these 110 families were also studied. No effort was made to adopt a random sampling procedure. Apart from one

TABLE 1

Population size, effective population size, number examined and the incidence of colourblindness among the four endogamous Nandiwalla groups

\begin{tabular}{|c|c|c|c|c|c|c|}
\hline \multirow{3}{*}{$\begin{array}{l}\text { Nandiwalla groups } \\
\text { 1. Patils }\end{array}$} & \multirow{3}{*}{$\begin{array}{l}\text { Population } \\
\text { size } \\
800\end{array}$} & \multirow{2}{*}{$\begin{array}{c}\text { Effective } \\
\text { population } \\
\text { size* } \\
240\end{array}$} & \multirow{2}{*}{\multicolumn{2}{|c|}{$\begin{array}{l}\text { Number } \\
\text { examined }\end{array}$}} & \multicolumn{2}{|c|}{ Colourblind } \\
\hline & & & & & \multirow{2}{*}{$\begin{array}{c}\text { No. } \\
0 \\
0\end{array}$} & \multirow{2}{*}{$\begin{array}{l}\text { per cent } \\
0 \cdot 00 \\
0 \cdot 0\end{array}$} \\
\hline & & & $\begin{array}{l}\mathrm{M} \\
\mathrm{F}\end{array}$ & $\begin{array}{l}332 \\
268\end{array}$ & & \\
\hline & & & $\mathbf{T}$ & 600 & 0 & $0 \cdot 0$ \\
\hline \multirow[t]{2}{*}{ 2. Chaugules } & 1150 & 345 & $\begin{array}{l}\mathrm{M} \\
\mathrm{F}\end{array}$ & $\begin{array}{l}338 \\
254\end{array}$ & $\begin{array}{l}1 \\
0\end{array}$ & $\begin{array}{l}0.3 \\
0.0\end{array}$ \\
\hline & & & $\mathbf{T}$ & 592 & 1 & $0 \cdot 17$ \\
\hline \multirow[t]{2}{*}{ 3. Komtis } & 460 & 138 & $\begin{array}{l}\mathrm{M} \\
\mathrm{F}\end{array}$ & $\begin{array}{l}167 \\
125\end{array}$ & $\begin{array}{l}0 \\
0\end{array}$ & $\begin{array}{l}0.0 \\
0.0\end{array}$ \\
\hline & & & $\mathbf{T}$ & 292 & 0 & $0 \cdot 0$ \\
\hline \multirow[t]{2}{*}{ 4. Daundiwallas } & 55 & 16 & $\begin{array}{l}\mathrm{M} \\
\mathrm{F}\end{array}$ & $\begin{array}{l}8 \\
9 \\
\end{array}$ & $\begin{array}{l}0 \\
0\end{array}$ & $\begin{array}{l}0.0 \\
0.0\end{array}$ \\
\hline & & & $\mathbf{T}$ & 17 & 0 & $0 \cdot 0$ \\
\hline \multirow[t]{2}{*}{ Total } & 2465 & - & $\begin{array}{l}\mathrm{M} \\
\mathrm{F}\end{array}$ & $\begin{array}{l}845 \\
656\end{array}$ & $\begin{array}{l}1 \\
0\end{array}$ & $\begin{array}{l}0 \cdot 10 \\
0 \cdot 00\end{array}$ \\
\hline & & & $\mathbf{T}$ & 1501 & $\overrightarrow{\mathrm{l}}$ & $\overline{0.06}$ \\
\hline
\end{tabular}

* This is a rough estimate based on the average derived by Salzano and Freire-Maia (1970), i.e. 30 per cent of the total population size. 
individual, all the Nandiwallas were illiterate and were asked to trace the lines on Ishihara plates 26 to 38 . The tests were performed in sufficient indirect daylight as recommended by Ishihara (1968).

\section{Results}

\section{(i) Population data}

It is noteworthy that out of a total of 1501 Nandiwallas examined, only one individual from Chaugule Putta was found to be abnormal (Deuteronope). The incidence of colourblindness is thus 0.3 per cent (only males considered) among the Chaugules. The three Mendelian isolates-Patils, Komtis and Daundiwallas-completely lack this allele (table 1).

\section{(ii) Family data}

The breakdown of 110 families with 334 children into endogamous groups is shown in table 2. All the matings, except one, were of the type normal $\times$ normal and all the children produced had normal colour vision.

TABLE 2

Data on 110 families investigated for inheritance of colourblindness

$\begin{array}{ccccc}\text { Nandiwalla groups } & \begin{array}{c}\text { Number of } \\ \text { families studied }\end{array} & \begin{array}{c}\text { Total number } \\ \text { of children }\end{array} & \overbrace{\text { Males }}^{\text {Children }} & \text { Females } \\ \text { 1. Patil Putta } & 35 & 101 & 55 & 46 \\ \text { 2. Chaugule Putta } & 41^{*} & 123 & 60 & 63 \\ \text { 3. Komti Putta } & 30 & 98 & 42 & 56 \\ \text { 4. Daundiwalla } & \mathbb{4} & \underline{12} & \overline{5} & \overline{7} \\ \text { Total } & \mathbb{1 1 0} & 334 & 162 & 172\end{array}$

* Except one mating among the Chaugule, father (colourblind) $\times$ mother (normal, all the remaining 109 were of normal $\times$ normal type and produced all the 334 children without defects of colour vision.

There was only one mating in which the father was colourblind and mother normal. This family belonged to Chaugule Putta and had six childrenfour sons, two daughters-with no defect of colour vision.

\section{Discussion}

The absence of the gene for colourblindness in three endogamous groups of Nandiwallas, and its rather low incidence ( 0.3 per cent) among the Chaugules is most noteworthy and assumes great significance when the incidence of this trait is considered in other populations from Western India. The incidence varies from 1 per cent to 10 per cent, with two populations having nil incidence-Devrukhe Brahmins (Malhotra, 1967) and Bohras (Hakim, 1971). Although in the former case the sample size is 200, in the latter case it is only 67 , which is rather small. In contrast, in the present series $60 \cdot 89$ per cent of all the Nandiwallas are included. Individually the four groups in our sample are represented as follows: Patils 75 per cent, Chaugules 51.47 per cent, Komtis 63.47 per cent and Daundiwallas 30.90 per cent. Thus considering the population size of these isolates, and the samples tested, it is most unlikely that colourblind individuals will be discovered among the Patils, Komtis and Daundiwallas. We therefore 
conclude that if the colourblind gene is present at all in these groups, the incidence will be of very low magnitude.

Since most of the studied populations of Western India have a relatively high incidence of colourblindness, why is it that the Nandiwallas have lost this gene? Unfortunately no data on this trait are available from a comparable nomadic group.

Post (1962) and Pickford (1963) have offered an interesting hypothesis to explain the heterogeneity observed in colourblindness in different parts of the world, including India. According to them, natural selection would tend to eliminate colourblindness in those populations which are most closely dependent on a hunting and food-gathering economy, and Post further observed that the number of colourblind would tend to increase by mutation if the rigours of natural selection against them were relaxed, as in the case of urban societies. The high incidence of colourblindness among the Brahmins and other caste groups of India has been explained by Pickford (1964) as "presumably the higher castes are farther removed from hunting and food gathering than the lower".

This model of Post and Pickford explains very well the status of colourblindness among the Nandiwallas. Although the Nandiwallas, strictly speaking are not hunters and food gatherers, their pattern of life is quite comparable to the hunting and food-gathering economy. The Nandiwallas are true nomads and operate in a wide area. The terrain is full of jungles and mountains. An important aspect of the Nandiwallas daily activity is that they go in the early hours of the morning to distant places to collect food (grass, leaves, etc.) from fields, and are thus prone to snake bites. In recent years a number of individuals have died of snake bite. This is not to suggest that the persons bitten by a snake were colourblind, but probably the colourblind individuals may experience a certain amount of difficulty in identifying snakes, particularly the green ones. Although the main occupation of the Nandiwallas is training bulls to perform certain tricks, including mock fights with the master, and moving ground in a set of hereditary villages performing for grains, cooked food, cash, etc., many of them hunt with the help of dogs, and go food gathering and even engage in freshwater fishing. It may be pointed out that the Nandiwallas have as yet not taken to modern medicine and instead rely on indigenous medicines and black magic for all sorts of ailments, including snake bite. The pattern of life led by the nomadic Nandiwallas therefore provides optimum opportunities for natural selection to operate on the disadvantageous genes.

The loss of the colourblind gene assumes greater significance when results of other markers among the Nandiwallas are also considered. Malhotra, Kate and Mutalik (1973) reported among the Nandiwallas absence of allele $p^{2}$ and $H p^{0}$ (at the haptoglobin locus), lowest frequency of allele $p^{1}=0.026$, ever recorded among Indian populations, lowest frequency of gene $H p^{1}$ ever reported in human populations, extremely high frequency of $\mathrm{Rh}(-)$ gene, striking low incidence of whorls and high occurrence of ulnar loops (Malhotra, Bhanu, Fulmali, Mutalik and Kate, 1974); and loss of the gene for attached ear lobe (Malhotra, 1973b).

The unique frequencies among the Nandiwallas were due largely to the effect of genetic drift and founder effect (Malhotra, Kate and Mutalik, 1973). These conclusions were confirmed in a subsequent paper on ear lobe attachment (Malhotra, 1973b) among these people. The effective 
population size of the four Mendelian isolates suggests the magnitude with which the gene drift (table 1) can operate on these groups.

Malhotra, Kate and Mutalik (1973a) had also suggested that the presence of G-6-PD deficiency and haemoglobin variants among the Nandiwallas was maintained because of the selective advantage afforded by these traits against malaria, etc. The present finding of loss of the colourblindness gene among the three Mendelian isolates thus adds yet another example of natural selection eliminating disadvantageous genes.

Acknowledgments.-We record our deepest sense of gratitude to the late Professor (Mrs) Irawati Karve, who had not only initiated this project in 1969 but had largely contributed to the design of the project.

We extend our greatest appreciation to Professor H. D. Sankalia, Director, Deccan College, for his constant encouragement and for making available to us the necessary funds for carrying out this project.

We are also extremely grateful to Shri. R. G. Marathe, and Shri. S. B. Khomne for their valuable assistance in collection of the data.

\section{References}

DUTTA, P. C. 1966. A review of the inherited defective colour vision variability and selection relaxation among Indians. Acta Genet., Basel, 16, 327-339.

HAKIM, s. м. 1971. Blood and serum groups and other genetical characters of some endogamous muslim groups. Unpublished Ph.D. thesis, Bombay University.

IsHiHARA, s. 1968. Tests for Colour-blindness. Kanehara Shuppan Co., Ltd., Tokyo, Japan. MAlHotra, к. c. 1967. The incidence of inherited defects of colour-vision in eight endogamous groups of Maharashtrian Brahmins. A. Ge. Me. Ge. (Rome), 16, 417-421.

MalHotra, K. C. 1972. Nandiwallas: Preliminary observations on a nomadic caste in Maharashtra. Indian Statistical Institute, Technical Report series, No. 14/72, 1-27

malhotra, к. с. 1973a. Pattern of nomadism. An example of social control mechanism and ecological pressures. (In Press.)

MALHOTRA, K. c. $1973 b$. Incidence and inheritance of ear lobe attachment among 4 nomadic groups. Am. F. Phys. Anthrop. (In Press.)

MALhOTRA, K. G., KATE, s. L., AND MUTALIK, G. s. 1973. The genetic composition and structure of a nomadic caste-cluster in Maharashtra. (In Press.)

MAlHOtRA, K. C., BHANU, B. V., FUlmali, P. M., MUTAlik, G. s., AND KaTe, s. L. 1974. Finger dermatoglyphics among 4 Mendelian Isolates-an example of genetic drift-and founder effect. Proc. 1st Ann. Conf. Ind. Soc. Human Genet., 12. (Abstract.)

PICKFORD, R. w. 1963. Natural selection and colourblindness. The Eugenics Review, 55, 97-101.

POST, R. H. 1962. Population differences in red and green colour vision deficiency: Review and a query on selection relaxation. Eugenics Quarterly, 9, 131-146.

salzano, F. M., ANd freire-Maia, N. 1970. Problems in Human Biology. Wayne State University Press, Detroit. 